\title{
Head teacher professional networks in Italy: preliminary results of a national survey ${ }^{1}$
}

\author{
Isabel de Maurissens ${ }^{a}$, Manuela Repetto ${ }^{b}$, Alessia Rosa ${ }^{c}$, Maria Chiara Pettenati ${ }^{d}$ \\ ${ }^{a}$ INDIRE, Italy, i.demaurissens@indire.it, ORCID 0000-0002-8547-9174 \\ $b$ \\ INDIRE,Italy,m.repetto@indire.it, ORCID 0000-0003-4685-1786 \\ cINDIRE,Italy, a.rosa@indire.it, ORCID 0000-0002-4572-0576 \\ $d$ \\ INDIRE Italy, mc.pettenati@indire.it, ORCID 0000-0001-7911-3435
}

\begin{abstract}
In this article, we present the preliminary results of a national survey conducted by INDIRE on head teachers communities and professional networks. About one-fourth of the total population of Italian public school leaders participated in the survey. One of the main intents of this research is to contribute to understanding of the phenomenon of professional networks frequented by school leaders and to pave the way for a further reflection on how to use such networks for head teachers' training so as to support their daily professional practice conducted too often in isolation.

This contribution is synergetic with what was envisaged by the new Italian school reform introduced with Law $107 / 2015$ and, in particular, with the roles of the school leaders and the networks. This research is conducted within the INDIRE DsinRete ${ }^{2}$ research project.
\end{abstract}

Keywords: head teacher, community, continuing professional development, survey

\section{Introduction}

This research originates from the need to investigate school leaders' networks and professional communities, because the topic has received little attention in national literature, so far. The existence of head teachers' professional networks is often taken for granted, but the networks themselves have little visibility today and available research to understand this topic is still in its infancy, to the state of our knowledge.

The expansion of the networking practices has so far been neither accompanied by public authorities' supportive action nor by the development of satisfactory organizational forms of management. It is possible that this is due to the lack of proper knowledge of how networks are born, how they function and what is their impact on schools.

A recent research conducted by IPRASE argues that "The leadership practices represent the driving element through which the headteacher and all who exercise leadership actions, shape the learning environment and thus the organizational effectiveness of the work conditions of teachers and students". To develop "professional capital" through the network is therefore of vital importance to sustain a more effective school autonomy.

The research hypothesis that underpins this work is that thinking about the network and using the network as a place for school leaders' training will contribute to supporting a more effective use of all the new tools provided by the Italian school reform (Law 107/2015) towards a more effective and efficient school autonomy (DPR 275/1999).

Networks are, in the very essence, the fabric of all complex systems, and nodes and links each permeate individuals' strategy to face the interconnected environment. Networks are governed by two principles: growth and preferential connection and this happens in all fields (e.g. in biology, physical sciences but also social sciences) (Barabàsi, 2004).

The intent of this first national survey is to highlight the roles of networks and professional communities of headmasters to provide a contribution to the state of the knowledge on how the networks originate, how they function and how they are governed; how they are structured and what is their life cycle; which functions and activities are

\footnotetext{
${ }^{1}$ The authors share the design of the research purpose and methodology and of the questionnaire items used in the survey. De Maurissens authored "Introduction", "1. Theoretical background" and part of "Conclusions"; M. Repetto authored "3. Data analysis and findings"; A. Rosa authored "2. Research methodology and tools"; M.C. Pettenati authored part of "Conclusions".

${ }^{2}$ http://www.indire.it/progetto/dsinrete/.
} 


\title{
Head teacher professional networks in Italy: preliminary results of a national survey
}

\author{
de Maurissens, Repetto, Rosa, Pettenati
}

perceived effective for their members; and to what extent participation in a professional network affects the management of one's own educational institution.

The results presented herein provide a first representation of the networks and professional communities, obtained by administering a questionnaire to a sample of about 1,500 Italian School leaders, and pave the way for providing a first national overview of these professional structures (De Maurissens et al., 2015). In the questionnaire, the respondents were confronted with the concept of networks in a broad sense, without specifying their real or virtual characteristics, so as to let school leaders describe the network reality they felt the closest to their professional practice.

\section{Theoretical background}

Why are networks so important? Networks, in all fields -social, scientific, technological, etc. -will dominate the new century in a much more extensive way than we are now capable of recognizing. Networks will shape the basic lines of our vision of the world in the times to come (Barabàsi, 2004). Barabàsi argues that small changes in the topology, involving only few nodes or links in the network, can open hidden passages and give rise to new unexpected possibilities (ibid.).

The assumptions of representations of the networks are inherently metaphorical but may be grouped, according to the literature, substantially in terms of space or relationships. According to an educational sociology perspective developed by Ball (2008), networks are messy hinterland; Ball argues that we are moving from a bureaucratic centralized government to a more informal power, boosted by self-organizing networks (Rhodes, 2008) to share resources and expertise, by a plurality of actors engaged in a thoughtful process of dialogue and information exchange. Networks can represent a non-vertical, democratized and decentralized governance and can constitute important tools in meeting the training needs of the school organizations in the territory (Biancato, 2014).

According to Gee's (2004) theory developed in relation to playing spaces, the networks can be also seen as affinity spaces, either virtual or physical, in which people are together because they share an interest or a cause in a common activity.

Another idea suggests also that networks are learning neighbourhoods, thus reversing the trend of stationary and motionless schools, with initiatives, people and relationships revolving from and around the school through its networks and professional communities (Mura in Cerini, 2015).

From a regulatory perspective, Art. 70 of the recent Italian School Reform Law (Law 107/2015) precisely addresses the issue of networking between educational institutions to enhance the professional resources, the common management of functions and administrative activities, as well as the implementation of projects or teaching, educational, sporting or cultural territorial interest, to be determined on the basis of agreements between autonomous schools of the same territorial area, defined Network Agreements with the support of the Local Ministry Authorities. It is therefore important to study whether "the development of school networks is intended to extinguish the school administration presence in its territory in relation to institutional decentralization" (Cerini, 2015). An even more recent regulation issued in specification of the earlier-cited law (MIUR AOODPIT 2151 7/6/2016) further defines the "area" and "purpose" networks of schools as two different enablers of improvement and innovation and defines the territorial provinces level as the ideal "space" within which networks should develop.

The mainstream literature on professional educational networks, both virtual and physical (Bolam et al., 2005; Brown \& Duguid, 1991, 2001; Cowan et al., 2004; Fielding et al., 2005; Hargreaves \& Fink, 2006; Hipp \& Huffman, 2007; Hord, 2004; Huffman, 2001; Jackson \& Temperley, 2007; Lave \& Wenger, 1991; Louis \& Leithwood, 1998; Stool et al., 2006; Wenger, 1998), were taken into account to identify the dimensions and indicators used to build the online survey described in the following paragraphs.

\section{Research methodology and tools}

In the research on the role of networks and communities in the professional development of head teachers, we used a mixed-methods approach (Gay et al., 2006), adopting a structure in which the process moves from the general to the specific.

We initially administered a questionnaire to collect information regarding head teachers' perceptions about the role of the professional communities, which is the objective of this article.

In a second phase, which is still in progress, we are using a focus group approach to provide a deeper understanding of head teachers' responses in the survey. Choosing the most appropriate data collection method is central to attaining a good response rate. We evaluated different types of data collection instruments, with many variants included in each.

The advantages of each method have been considered within the context of the target population, the survey objectives, the type of information to be collected, the research budget and the time constraints.

In Italy, the population of head teachers involves approximately 7,000 subjects and the framework of the networks is diversified; therefore, an Internet survey has been considered more functional for our research.

The survey model allowed us to achieve the following: 


\section{Head teacher professional networks in Italy: preliminary results of a national survey}

de Maurissens, Repetto, Rosa, Pettenati

- $\quad$ gather large-scale data in order to make generalizations,

- $\quad$ generate statistically manageable data and

- $\quad$ gather context-free data.

The questionnaire was built around ten different dimensions derived from the analysis of the literature on professional networks of practice: the territorial dimension (network localization and extension), the diachronic dimension (participation frequency and continuity, network life cycle and lifespan), the organizational dimension (network structure, leadership type, network openness level, participants' role and involved participants), the participative dimension (participation level of the individual and of the members), the identity dimension (identification with the network), the operational and impact dimension (practices developed by the individual and by the network, its strengths and weaknesses, impact of the network and the enabled activities), the professional dimension (professional development enablers), the dialogic dimension (width and typology of the network interactions), the communication dimension (network promotion strategy), the instrumental -technological dimension (tools and environments used for networking).

The ten dimensions are further articulated in terms of indicators, and each indicator is therefore addressed by one or more questionnaire items with a total of 52 questions. An identity section is also envisaged to map respondent's name, school location, school type, years of service as a teacher and subject matter, years of service as school leader, education and contact address.

Questions were aimed at highlighting the elements that contribute to the functioning of the networks from two points of view: the continuous professional development and the support to school autonomy.

We defined a series of multiple-choice questions, where the range of choices was designed to capture the likely range of responses to given statements.

The questionnaire was built by the research group and validated by a group of 12 representative headmasters chosen nationwide according to criteria of geographical representation, school level, school type, integration within a network and interest in the research topic. This group of experts constituted the expert board throughout the research.

In the first step, the group of experts, through an open-ended questionnaire, assessed the understandability of the questions, the relevance of the covered topics and the time allowed for answering.

In the second phase, a focus group was conducted with the same group of experts, to validate again the questionnaire submitted online and implement some sections.

Eventually, the questionnaire was modified in response to the experts' indications.

The researchers advertised the opportunity of access to this online questionnaire with the collaboration of the ministerial offices, the school boards, the associations and the official website of INDIRE ${ }^{3}$

Multiple contacts via postal mail and email, if available, were made to encourage participation in the online survey.

Eligibility was limited to all Italian public school head teachers. The sample was designed to maximize comparability of the networks' and the schools' features.

The invitation letter described the nature and purpose of the survey and included the uniform resource locator (URL) and other information on access to the online survey.

An initial email was also sent to those with email addresses containing information similar to that on the advance letter, in addition to a hyperlink to the survey login. The online survey was opened in November 2015 and it was closed in January 2016. Data gathered through the online questionnaire were analysed using univariate descriptive statistics.

The sample of respondents to the online survey consisted of 1,571 head teachers, comprising $68 \%$ females and $32 \%$ males (reflecting the national gender distribution, because in 2015, female presence in the whole country was about $63 \%$ ), which represents about one-quarter of the whole Italian head teacher population. The scholastic institutes managed by them are mainly the Comprehensive level for $59 \%$ of heads and upper secondary level for $29 \%$, while $8.5 \%$ of them lead a primary school and 3.5\% a lower secondary school. Furthermore, $43 \%$ of respondent head teachers and their schools are located in the north of Italy, $18 \%$ in the centre and $39 \%$ in the south.

Because the professional networks described by the respondents were 1,385 in total, heads belonging to a network are at least $87 \%$ of the sample.

\section{Data analysis and findings}

How are the networks born and can we trace their borders? According to the respondents, the large majority of professional networks have originated from the territory of already established ones, while $30 \%$ of the sample are virtual networks or became virtual afterwards; $65 \%$ of the networks have a local extension, $17 \%$ a regional one and another $17 \%$ a national extension.

As for the composition of these professional networks, $31 \%$ of them are made exclusively of head teachers, but more than half of them are made up also of teachers (54\%), administrative managers (30\%) and other profiles (15\%). Almost half of all cases within the structure of these networks, the majority of which -considering their life cycles -are at a

\footnotetext{
${ }^{3} \mathrm{http}: / / \mathrm{www}$. indire.it/progetto/dsinrete/
} 
stage of "growth" (42\%) or of "maturity" (39\%), is mainly distributed, while $35 \%$ of them are decentralized and only $19 \%$ are centralized. Hence, the most widespread models of structures are organized into various small groups of persons (decentralized) or constituted of a number of capillary distributed people. The subdivision of roles of members is compatible with these not hierarchical models of structures, because in almost half of the cases, the subjects have chosen their own roles and, in $30 \%$ of cases, these roles have spontaneously arisen. In the large majority of the networks, their members meet at least once a month and $22 \%$ meet with the same regularity at a distance, mainly using synchronous web tools.

According to the respondents, their networks established relationships with up to five other professional networks in $61 \%$ of cases, with more than five networks in $10 \%$ and with no network in $29 \%$ of cases. These partner networks are mainly local (67\%), while 33\% are transnational (European) and $27 \%$ are national. The respondents declared that, among other types of institutions with whom their network activated collaboration, more than half of the cases involved formal head teacher associations, local authorities or universities and research bodies; however, the list also comprises schools (22\%), formal teacher associations (20\%) and enterprises $(16 \%)$.

Respondents were asked through which functions and activities their network could be considered useful and effective for its members. As shown in Table 1, 64\% of head teachers consider their network useful both for promotion of educational initiatives for the professional development of school personnel and for the support to solve contingent professional troubles; next comes cooperation on common projects $(60 \%)$, sharing of knowledge and innovative educational practices (54\%), documentation sharing (41\%) and initiatives of research and experimentation (35\%). In three-quarters of the networks, the educational initiatives are organized because of the relationships established with other networks or institutions.

Table 1. Distribution of activities making the network useful.

\begin{tabular}{lllll}
\hline $\begin{array}{l}\text { Promotion of educational } \\
\text { initiatives for school } \\
\text { personnel }\end{array}$ & $\begin{array}{l}\text { Support to solve } \\
\text { contingent professional } \\
\text { troubles }\end{array}$ & $\begin{array}{l}\text { Cooperation on } \\
\text { common projects }\end{array}$ & $\begin{array}{l}\text { Documentation } \\
\text { sharing }\end{array}$ & $\begin{array}{l}\text { Sharing of knowledge and } \\
\text { innovative educational } \\
\text { practices }\end{array}$ \\
\hline $64.1 \%$ & $64 \%$ & $59.9 \%$ & $40.7 \%$ & $54.2 \%$ \\
and experimentation & $34.5 \%$
\end{tabular}

Regarding the promotion of educational activities targeted at head teachers themselves, $73 \%$ of respondents declared that their networks promote informal learning through continuous exchanges among members; $60 \%$ of the networks organize formal courses and workshops, while only $10 \%$ of them arrange online courses.

The education activities organized by one's own network is perceived by $44 \%$ of heads as one of the strengths of that network, together with collaboration (78\%), the reinforcement of relationships within local territory (38\%), the achievement of specific projects $(37 \%)$ or the saving and optimization of resources $(29 \%)$. The need to consolidate the network organization (44\%) and coordination problems $(25 \%)$ are instead the main points of weaknesses, although almost $30 \%$ of head teachers did not notice any critical element.

The large spectrum of activities organized by networks in which head teachers are involved is reflected also in the role fulfilled by respondents in their own network, declaring to be very active in two-thirds of all cases; only $20 \%$ are occasional members involved in few activities promoted by the network, while $10 \%$ of heads define themselves as mere observers. A great majority of respondents developed a strong sense of belonging to their network, because they declare that they identified with its mission and aims, as well as feeling highly motivated to share their professional knowledge with their colleagues; moreover, their membership of that network helps them to prevent and reduce isolation, a very widespread condition among head teachers.

Isolation experience is probably contained also because of the presence of social media as tools to interact with other members of the network, which are used mainly from school (78\%), as well as from home (68\%), but even on the move (34\%): apart from phone and email, which remain the indisputable means of communication, $42 \%$ of school heads use instant messaging tools and $20 \%$ use social networks.

Participation in a professional network stimulated the growth of head teachers' knowledge, skills and relationships, affecting the management of their own scholastic institution. Table 2 shows the impact of the professional network on innovation in teaching and learning processes, according to the respondents. Considering the sum of percentages between moderate and high, it emerges that the improvement touches all the listed issues, ranging from 54\% of improvement in the context of student dropout recovery to $68 \%$ of pedagogical and methodological aspects. 


\begin{tabular}{|c|c|c|c|c|c|}
\hline \multicolumn{6}{|c|}{ Learning and teaching innovation } \\
\hline & $\begin{array}{l}\text { Learning outcomes } \\
\text { enhancement }\end{array}$ & $\begin{array}{l}\text { Improvement of pedagogical and } \\
\text { methodological aspects }\end{array}$ & $\begin{array}{l}\text { Dropout } \\
\text { recovery }\end{array}$ & Inclusion & $\begin{array}{l}\text { Curriculum } \\
\text { change }\end{array}$ \\
\hline None & $8.1 \%$ & $7.4 \%$ & $8.2 \%$ & $6.6 \%$ & $7.4 \%$ \\
\hline Low & $30.4 \%$ & $25.0 \%$ & $37.5 \%$ & $28.1 \%$ & $33.9 \%$ \\
\hline Moderate & $50.3 \%$ & $52.1 \%$ & $42.5 \%$ & $47.4 \%$ & $43.5 \%$ \\
\hline High & $11.2 \%$ & $15.5 \%$ & $11.8 \%$ & $17.9 \%$ & $15.2 \%$ \\
\hline
\end{tabular}

More controversial results are those arising from Table 3, fluctuating from a remarkable improvement of teacher training initiatives (78\% considering also "moderate") and enhancement of head teacher's self-education (77\%) to a low impact on extracurricular opportunities (just 31\% of improvement) and on the training of school personnel (34\%). Moreover, knowledge and opportunities acquired in the network also increased the school educational offer (62\%).

Table 3. Impact on school educational offer

\begin{tabular}{lllll}
\hline Education & \multicolumn{5}{c}{} \\
\hline None & Teacher professional development & Training of school personnel & Extracurricular opportunities for students & Self-education \\
Low & $4.5 \%$ & $25.6 \%$ & $20.7 \%$ & $5.0 \%$ \\
Moderate & $52.2 \%$ & $40.0 \%$ & $38.1 \%$ & $18.2 \%$ \\
High & $26.0 \%$ & $26.4 \%$ & $29.8 \%$ & $48.6 \%$ \\
\hline
\end{tabular}

All the leadership affordances of the respondents have improved due to their participation in a professional network (Table 4): improvement percentage varied from 50\% for attraction of funding for their school, to $71 \%$ for innovation of external relationships. The only one discordant value is that concerning student enrolment, which has increased in $28 \%$ of cases.

Table 4. Impact on leadership affordances

\begin{tabular}{|c|c|c|c|c|c|c|c|c|c|}
\hline \multicolumn{10}{|c|}{ Leadership } \\
\hline & $\begin{array}{l}\text { Simplification } \\
\text { of } \\
\text { administrative } \\
\text { procedure }\end{array}$ & $\begin{array}{l}\text { Improvement } \\
\text { of school self- } \\
\text { evaluation } \\
\text { capabilities }\end{array}$ & $\begin{array}{l}\text { Organizational } \\
\text { innovation }\end{array}$ & $\begin{array}{l}\text { Innovation of } \\
\text { internal } \\
\text { relationships } \\
\text { (school } \\
\text { personnel, } \\
\text { students) }\end{array}$ & $\begin{array}{l}\text { Innovation of } \\
\text { external } \\
\text { relationships } \\
\text { (other schools, } \\
\text { communities, } \\
\text { families, third } \\
\text { sector, etc.) }\end{array}$ & $\begin{array}{l}\text { Increase in } \\
\text { student } \\
\text { enrolments }\end{array}$ & $\begin{array}{l}\text { Attraction } \\
\text { of funding } \\
\text { for the } \\
\text { school }\end{array}$ & $\begin{array}{l}\text { Greater } \\
\text { continuity } \\
\text { among } \\
\text { school } \\
\text { grades }\end{array}$ & $\begin{array}{l}\text { Greater } \\
\text { visibility of } \\
\text { the school in } \\
\text { the } \\
\text { community }\end{array}$ \\
\hline None & $14.7 \%$ & $8.3 \%$ & $5.3 \%$ & $9.1 \%$ & $6.7 \%$ & $29.9 \%$ & $15.6 \%$ & $10.1 \%$ & $12.0 \%$ \\
\hline Low & $28.0 \%$ & $25.4 \%$ & $24.2 \%$ & $34.2 \%$ & $28.5 \%$ & $42.1 \%$ & $34.8 \%$ & $26.9 \%$ & $29.8 \%$ \\
\hline Moderate & $41.9 \%$ & $45.5 \%$ & $51.5 \%$ & $44.7 \%$ & $46.7 \%$ & $22.8 \%$ & $38.5 \%$ & $44.9 \%$ & $40.8 \%$ \\
\hline High & $15.5 \%$ & $20.8 \%$ & $18.9 \%$ & $12.0 \%$ & $18.0 \%$ & $5.2 \%$ & $11.0 \%$ & $18.1 \%$ & $17.5 \%$ \\
\hline
\end{tabular}

The data shown in the Tables $2-4$ as a whole suggest to what extent participation of head teachers in a professional network is not a goal in itself, but has relevant consequences on the management and the development on one's own educational institution.

\section{Conclusions}

Preliminary results presented in this research report data from a national survey conducted on 1,571 Italian head teachers, mirroring the present situation of their involvement in professional networks and communities. The 1,571 school leaders who responded to the survey, evenly geographically distributed throughout the country and with prevalence of respondents of female gender, revealed the existence of 1,385 active networks, i.e. an involvement in networks for approximately $88 \%$ of the investigated sample, among which two-thirds declared very active behavior and developed a strong sense of belonging to their network. The characterization of the networks that emerges from the research leads us to obtain a glimpse of how the networks, mainly arising from existing ties stemming from within the territory, have -to date -only limited online evolution and maintain a prevalence of territoriality (at a local or at the most regional level, and very little at the national level). Networks are also largely open to participations that are not limited to the professionalism of school leaders but very often involve other professionals from the school (e.g. teachers and other administrative school staff). The networks' structure is distributed or decentralized in most cases, while the 
roles are increasingly informal; external relationships and collaborations with other networks or with institutions are widespread. The great majority of the networks is itself networked with other networks, with the higher level networking allowing to overcome the territorial boundaries, as well as borders that exceed, very often, the region and often the country.

Active networks play a primarily educational function; through networks - often more informally than formally -one of the most important activities to which respondents give value is the support extended to the resolution of problems relating to everyday professional practices, documentation and sharing of practices and experiences as well as research and innovation that can also be translated into real projects.

All of these observations point to the fact that approximately one-third of the respondents do not identify critical issues to be reported as network weaknesses nor do they consider significantly such weaknesses as being organizational (e.g. coordination, contacts, roles, etc.). Instead, several of the participants highlight the importance of consolidating the network, identifying that the very nature of weak links that characterize the professional networks, provide significant support but is likely to be evanescent. The need for network strengthening and stabilization is therefore strongly perceived. On the other side, the network represents collaboration, sharing, cooperation and training opportunities, guidance, shared projects and peer learning, thus showing that strengths enhance the network of relationships within the territory from which, very often, the network itself is originated.

One of the most interesting results of this survey is the fact that school leaders surveyed consider the impact of the networks in three key aspects of their professional practice: educational innovation, training and leadership. Noteworthy, what emerges is the network being a support to the improvement process (of learning, of methodological educational aspects, of inclusion, of the opportunities for teacher training and self-training, self-assessment and of the administrative processes) but also as a support to innovation processes (organizational, relational, of digital processes and of the curriculum).

These results confirm the hypothesis that the weak links create opportunities and innovation and play a crucial role in our communication with the outside world (Granovetter, 1998). Networks are therefore good places that can promote the development of these fertile types of links and a good place to promote a Common Culture education instead of a Competitive Culture education, as suggested by Biesta (2016).

In the second phase of this research, which is still in progress, we are using a focus group approach to provide deeper understanding of head teachers' responses to the survey questionnaire.

Further research is also needed to define a more specific classification of the existing head teacher networks (real, virtual and hybrid), in which key factors associated with good functioning of the network need to be underlined and deeply discussed so as to better understand this phenomenon and to infer the potential of these networks for professional development of headmasters. According to this perspective, a relevant topic is the assessment of the real training impact of the networks and communities in the school heads professional practice. A set of indicators should be developed starting from the results proposed by Romano et al. (2008) so as to understand whether the individual's perception of networking corresponds to a real impact in the school in which the individual operates, as well as how, when and under which circumstances this occurs.

A topic that needs further investigation is related to the type and the quality of relationships that are triggered by the networks, because this aspect is not represented by this survey's results. Eventually, another topic closely related to this research, which will be investigated in the near future, is also the understanding of the real transfer of knowledge from the head teacher via his/her participation in the network to their school, i.e. the Knowledge Transfer, accounting for the causal link between the head teacher professional characteristics and the students' learning outcomes, as confirmed by the Education Effectiveness Research approaches (Reynolds et al., 2014).

\section{References}

Ball, S.J. (2008). New Philanthropy, new Networks and new Governance in Education, Political Studies, vol. 56, $747-$ 765

Barabarsi, A.L. (2004). Link la scienza delle reti. Torino: Einaudi

Biancato, L. (2014). L'autonomia si rafforza con le reti. Il modello del Centro Territoriale per i Servizi Scolastici (CTSS) di Bassano del Grappa - Asiago, Scuola Democratica, Settembre-Dicembre (3), pp. 723-730.

Biesta, G. (2016) Improving education through research? From effectiveness, causality and technology to purpose, complexity and culture. Policy Futures in Education, 14(2) 194-210

Bolam, R., McMahon, A., Stoll, L., Thomas, S., Wallace, M., Greenwood, A., Hawkey, K., Ingram, M., Atkinson, A. \& Smith, M. (2005). Creating and sustaining effective professional learning communities. Research Report 637. London: DfES and University of Bristol.

Brown, J. S., \& Duguid, P. (1991). Organizational learning and communities of practice: Toward a unified view of working, learning, and innovation. Organization Science, 2(1), 40-57.

Brown, J. S., \& Duguid, P. (2001). Knowledge and organization: A social-practice perspective. Organization Science, 12(2), 198-213. 


\section{Head teacher professional networks in Italy: preliminary results of a national survey \\ de Maurissens, Repetto, Rosa, Pettenati}

Cerini, G. (Ed.) (2015). Dirigenti scolastici di nuova generazione, Santarcangelo di Romagna, Maggioli Editore.

Cowan, D’E., Fleming, G.L., Thompson, T.L. \& Morrisey, M.S. (2004). Study description: Investigating five PLC schools. In S. M. Hord (ed), Learning together, leading together: Changing schools through professional learning communities. New York: Teachers College Press.

De Maurissens, I., Repetto, M.; Rosa, A., Pettenati, M. C. (2015). Indagine nazionale sulle reti e Comunità di pratica per Dirigenti scolastici. In Rui M., Messina L., Minerva T. (eds.), Teach Different! Proceedings della Multiconferenza EMEMITALIA2015, Genova University Press: Genova.

Fielding. M., Bragg, S., Craig, J., Cunningham, I., Eraut, M., Gillinson, S., Horne, M., Robinson, C. \& Thorp, J. (2005). Factors influencing the transfer of good practice. DfES Research Report RR 615, University of Sussex.

Gay, L., Mills, G., Airasian, P. (2006). Educational research: Competencies for analysis and application. New York: Prentice Hall.

Gee, J. P. (2004). Situated Language and Learning: A Critique of Traditional Schooling. New York: Routledge

Granovetter, M. (1998). La forza dei legami deboli, Napoli, Liguori.

Hargreaves, A. \& Fink, D. (2006). Sustainable leadership. London: Wiley \& Son.

Hipp, K.A. \& Huffman, J.B. (2007). Using assessment tools as frames for dialogue to create and sustain professional learning communities. In L. Stoll \& K.S. Louis (eds), Professional learning communities: Divergence, depth and dilemmas. Maidenhead: Open University press.

Hord, S. (2004). Professional learning communities: An overview. In S. Hord (ed), Learning together, leading together: Changing schools through professional learning communities. New York: Teachers College Press.

Huffman, J.B. (2001). The role of shared values and vision in creating professional learning communities. Paper presented to the Annual Meeting of the American Educational Research Association, Seattle, April.

Jackson, D. \& Temperley, J. (2007). From professional learning community to networked learning community. In L. Stoll \& K.S. Louis (eds), Professional learning communities: Divergence, depth and dilemmas. Maidenhead: Open University Press.

Lave, J. \& Wenger, E. (1991). Situated learning: Legitimate peripheral participation. Cambridge: Cambridge University Press.

Louis, K.S. \& Leithwood, K. (1998). From organizational learning to professional learning communities. In K. Leithwood \& K.S. Louis (eds), Organizational learning in schools. Lisse, The Netherlands: Lisse, Swets and Zeitlinger.

Marzano, R.J. Waters, T. Mc Nulty, B.A. (2005). School leadership that works: from research to results. USA: ASCD Publications

Paletta, A. (Ed.) (2015). Dirigenti leader per l'apprendimento. Retrieved from http://www.iprase.tn.it/pubblicazioni/scheda-documento/?node=workspace://SpacesStore/9cbf0111-ae99-44ebad76-d3fcdac2e628. ISBN/ISSN: 978-88-7702-398-8

Reynolds, D., Sammons, P., De Fraine, B., Van Damme, J., Townsend, T., Teddlie, C., \& Stringfield, S. (2014). Educational effectiveness research (EER): A state-of-the-art review. School Effectiveness and School Improvement, 25(2), 197-230.

Romano, G., \& Trentin, G. (2008) Valutare gli effetti dell'apprendimento informale prodotto nelle comunità professionali online. Tecnologie Didattice. 44(2), 57-61.

Stoll, L., Bolam, R., McMahon, A., Thomas, S., Wallace, M., Greenwood, A. \& Hawkey, K. (2006). Professional learning communites: Source materials for school leaders and other leaders of professional learning. London: Innovation Unit, DfES, NCSL and GTC.

Wenger, E. (1998). Communities of practice: Learning, meaning and identity. New York: Cambridge University Press. 